\title{
Impact of water deficit stress on biomass production of different gladiolus cultivars under rainfed condition
}

\author{
Ranjan Das ${ }^{1}$, K. Bhagawati ${ }^{2 *}$, A. Boro', T. Medhi ${ }^{1}$ \\ 'Department of Plant Physiology, Assam Agricultural University, Jorhat, Assam, India, ${ }^{2}$ Department of NICRA, ICAR Research \\ Complex for NEH Region, Arunachal Pradesh Centre, Basar, Arunachal Pradesh, India
}

Received: 04.07.2015

Accepted: 23.07.2015

Published: 23.07 .2015

*Address for correspondence:

K. Bhagawati, ICAR Research

Complex for NEH Region,

Arunachal Pradesh Centre,

Basar, Arunachal Pradesh,

India. E-mail: kaushik.iasri@ gmail.com

\begin{abstract}
Among environmental stresses, water deficit stress was recognized to be one of the most adverse factors for plant growth and productivity. The study aimed to comparatively evaluate the impact of water deficit stress on biomass of seven cultivars of gladiolus in terms of leaf area duration (LAD) and net assimilation rate (NAR) under rainfed conditions in northeastern region of India. In addition, productions in terms of marketable spikes were compared. The parameters were measured using standard procedures. Comparatively, higher LAD (116 days) and NAR were found in cultivars Aarti (116 days and $1.62 \mathrm{~g} / \mathrm{cm}^{2} /$ day $\times 10^{-3}$ respectively) and Suchitra (98.0 days and $1.10 \mathrm{~g} / \mathrm{cm}^{2} /$ day $\times 10^{-3}$ ) which account for their higher biomass production with larger spike size with good numbers of flowers. The highest marketable spikes (71111.11 spikes/ha) was found in cultivar Aarti followed by Suchitra (68148.14 spikes/ha) which might be due to its comparatively higher biomass production and less deviation, during stress condition, from normal characteristics. The tolerant cultivars are those that can adapt to the change without much change in their normal growth. Moreover, the responses of those species are commercially acceptable that promote adaptation without compromising much with the plant growth and crop production.
\end{abstract}

KEY WORDS: Biomass, gladiolus, leaf area duration, net assimilation rate, water stress

\section{INTRODUCTION}

Stress may be defined as the altered physiological condition caused by environmental factors that tends to alter equilibrium (Shao et al., 2008). Of various ecological factors, water is one of the most important determining factors for plant growth and development; and water deficit stress plays a significant role in inhabiting normal performance and yield of crops (Jaleel et al., 2007). It trigger a wide variety of plant responses, ranging from physiological, anatomical, and genetic variations influencing plant growth and performance (Chartzoulakis et al., 2002; Jaleel et al., 2008; Shao et al., 2008; Pompelli et al., 2010; Gratani et al., 2013). The impact of water stress on plant growth can be seen in various level ranging from cellular to community (Colom and Colom, 2007; Blumwald et al., 2004).

One way to ensure better performance of crops under water deficit stress condition should involve better use of water by selection and development of crop cultivars that are tolerant (Jaleel et al., 2007). Every plant cultivars responses to water deficit stress up to a certain degree, but their intensity vary with species. Plants underwent several physiological, morphological and anatomical changes to increase its tolerance toward adverse environmental conditions. However, those species can be regarded as economically tolerant that deviate minimum from its normal growth and performance. The common adverse effect of water stress on the plant is a reduction of biomass production (Zhao et al., 2008). Morphological parameters such as fresh weight and dry weight have a profound effect in water-limited conditions (Shao et al., 2008). Reduction of biomass in terms of number and size of leaves and flowers, shoot length, etc. are deleterious especially for cut flowers such as gladiolus. Gladiolus belonging to the family Iridaceae is an important commercial ornamental crop of northeastern region of India. However, the climatic variation causes water deficit condition during growing season due to erratic 
rainfall that has a profound impact on its production and productivity. The objective of current study was to evaluate the impact of water deficit stress on biomass of seven popularly grown cultivars of gladiolus in terms of relative variation in their leaf area duration (LAD) and net assimilation rate (NAR; the rate of increase of biomass per unit of leaf area). Finally, their production in terms of marketable spikes was compared.

\section{MATERIALS AND METHODS}

\section{Experimental Site}

The investigation was conducted in the year 20102014 at the horticultural farm of Assam Agricultural University, Jorhat, Assam. The site is located nearly around $26^{\circ} 45^{\prime} 28.34^{\prime \prime} \mathrm{N}$ and $94^{\circ} 12^{\prime} 35.36^{\prime \prime} \mathrm{E}$ in the northeastern part of India.

\section{Experimental Layout}

The seven most popularly grown gladiolus cultivars viz. Suchitra, Jacksonville Gold, American Beauty, White Prosperity, Blue Isle, Aarti and Apollo, were grown under a similar condition in the horticultural farm for the study. The experiment was designed in Randomized Block Design and consisted of seven treatments and replicated thrice. Half dose of nitrogen and full dose of phosphorus and potassium were applied as basal doses. The crop was top dressed with remaining half dose of $\mathrm{N}$ at 45 days after planting. Well decomposed farm yard manure at $6 \mathrm{~kg} / \mathrm{m}^{2}$ was applied at the time of land preparation and 10 days prior to planting. Planting of cultivars was carried out in the first week of November 2010. Corms of three cultivars were Dehusked. The experimental site was kept weed-free by periodic hand weeding. Regular irrigation was given at an interval of 7-8 periods only.

\section{Meteorological Parameters}

The meteorological data during the period of investigation with monthly averages were taken at the Meteorological Observatory of Assam Agricultural University, Jorhat. The total rainfall during the crop season (November 2011 to April 2012) was $204.5 \mathrm{~mm}$. The rainfall was found to be lowest in the month of December $(10.4 \mathrm{~mm})$ and highest in the month March $(76.4 \mathrm{~mm})$. The month of November had the highest number of rainy days (13 days), and December, January, and February (3 respectively) continuously had the lowest number of rainy days. The temperature was at its maximum in the month of April $\left(28.7^{\circ} \mathrm{C}\right)$ and minimum at December $\left(11.8^{\circ} \mathrm{C}\right)$. Soil moisture content was measured using gravimetric method (Dastane, 19678) (Table 1).

\section{LAD and NAR}

The biomass accumulated during the observation period was computed as the difference between initial and final dry matter and expressed as g/plant (gram per plants). LAD takes into account, both the duration and extent of photosynthetic tissue of crop canopy. LAD correlates dry matter with leaf area index. LAD is given by:

$\mathrm{LAD}=\left\{\left(\mathrm{L}_{1}+\mathrm{L}_{2}\right) / 2\right\} /\left(\mathrm{t}_{2}-\mathrm{t}_{1}\right)$, where $\mathrm{L}_{1}$ and $\mathrm{L}_{2}$ are initial and final leaf area indices during the observation period $\left(\mathrm{t}_{2}-\mathrm{t}_{1}\right)$.

The NAR expressed in $\mathrm{g} / \mathrm{cm} /$ day was determined as the ratio of total dry matter during the period and LAD.

\section{Statistical Analysis}

The analysis was done using analysis of variance followed by Duncan's Multiple Range Test. The values are mean \pm standard deviation for all samples. $P \leq 0.05$ was considered as significant.

\section{RESULTS}

The cultivars have a wide variation in terms of LAD (Figure 1). Highest LAD value was observed in cultivar Aarti (116 days) followed by Suchitra (98.00 days) and Blue Isle (94.92 days) which were found to be

Table 1: Average monthly rainfall, number of rainy days, and soil moisture data of growing months during the period of experiment (2010-2014)

\begin{tabular}{lccc}
\hline Month & $\begin{array}{c}\text { Total rainfall } \\
(\mathrm{mm})\end{array}$ & $\begin{array}{c}\text { Total rainy days } \\
\text { per month }\end{array}$ & $\begin{array}{c}\text { Soil moisture } \\
(\%)\end{array}$ \\
\hline November & 20 & 13.1 & 23.6 \\
December & 20 & 2.7 & 21.4 \\
January & 19.5 & 2.8 & 17.7 \\
February & 28.2 & 2.6 & 18.2 \\
March & 78.1 & 10.2 & 24.8 \\
April & 52.02 & 10.5 & 24.0 \\
\hline
\end{tabular}

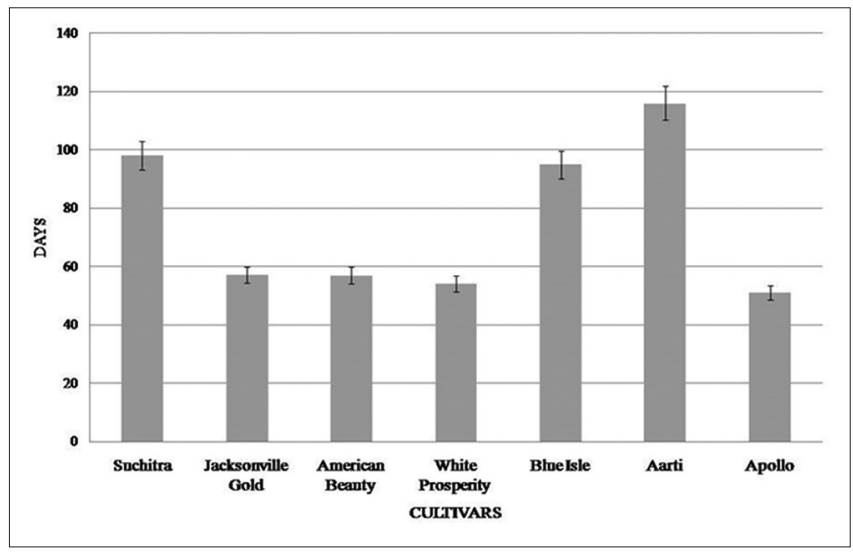

Figure 1: Relative variation of leaf area duration among the cultivars 
significantly higher $(P<0.05)$ than that of cultivar Apollo (51 days), White Prosperity (54.12 days), American Beauty (56.92 days), and Jacksonville Gold (57.12 days) (Table 2). NAR had considerable variations among the cultivars (Figure 2), with highest NAR value in cultivar Aarti $\left(1.62 \mathrm{~g} / \mathrm{cm} /\right.$ day $\left.\times 10^{-3}\right)$ followed by Suchitra $\left(1.10 \mathrm{~g} / \mathrm{cm}^{2} /\right.$ day $\left.\times 10^{-3}\right)$. While NAR value was found to be lowest in the cultivar Apollo $\left(0.54 \mathrm{~g} / \mathrm{cm}^{2} /\right.$ day $\left.\times 10^{-3}\right)$ followed by Jacksonville Gold $\left(0.81 \mathrm{~g} / \mathrm{cm}^{2} /\right.$ day $\left.\times 10^{-3}\right)$ (Table 2). The NAR value of Apollo and Suchitra was found to be significantly higher than rest of the cultivars.

The results also reveals that the highest marketable spike was found in cultivar Aarti (71111.11 spikes/ha) followed by Suchitra (68184.14 spikes/ha) which were significantly higher than that of Apollo (34074.44 spikes/ha), American Beauty (50370.36 spikes/ha), Blue Isle (51851.85 spikes/ha) (Table 2).

\section{DISCUSSIONS}

The decrease in LAD under drought condition is in accordance with previous findings (Thakur and Kaur,

Table 2: Variability of LAD, NAR, and marketable spikes in different gladiolus cultivars at different stages of crop growth period under rainfed condition

\begin{tabular}{lccc}
\hline Cultivar & $\begin{array}{c}\text { LAD } \\
(\text { days })\end{array}$ & $\begin{array}{c}\text { NAR } \\
\left(\mathrm{g} / \mathrm{cm}^{2} / \text { day } \times 10^{-3}\right)\end{array}$ & $\begin{array}{c}\text { Marketable } \\
\text { spikes/ha }\end{array}$ \\
\hline Suchitra & $98.00^{\mathrm{a}}$ & $1.10^{\mathrm{a}}$ & $68148.14^{\mathrm{a}}$ \\
Jacksonville gold & $57.12^{\mathrm{b}}$ & $0.84^{\mathrm{c}}$ & $53333.33^{\mathrm{c}}$ \\
American beauty & $56.92^{\mathrm{b}}$ & $0.91^{\mathrm{c}}$ & $50370.36^{\mathrm{c}}$ \\
White prosperity & $54.12^{\mathrm{b}}$ & $0.91^{\mathrm{c}}$ & $53333.33^{\mathrm{c}}$ \\
Blue isle & $94.92^{\mathrm{a}}$ & $0.98^{\mathrm{c}}$ & $51851.85^{\mathrm{c}}$ \\
Aarti & $116.00^{\mathrm{a}}$ & $1.62^{\mathrm{a}}$ & $71111.11^{\mathrm{a}}$ \\
Apollo & $51.00^{\mathrm{b}}$ & $0.54^{\mathrm{b}}$ & $34074.44^{\mathrm{b}}$ \\
Mean & 75.44 & 0.98 & 54603.22 \\
SE & 10.07 & 0.12 & 4664.80 \\
\hline
\end{tabular}

The values with same superscripts ( $a$ or $b$ or $c$ ) are not significantly different while with different superscript are significantly different at $P<0.05$. LAD: Leaf area duration, NAR: Net assimilation rate, SE: Standard error

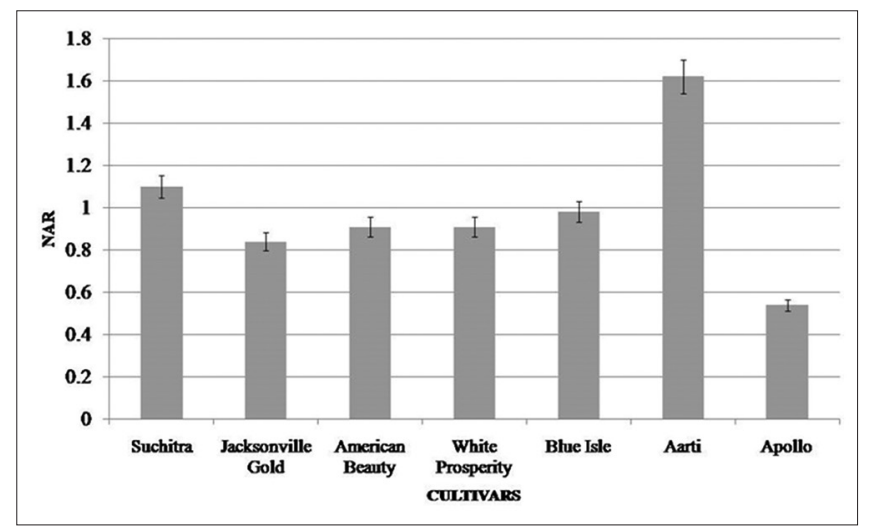

Figure 2: Relative variation of net assimilation rate among the cultivars
2001; Shivay et al., 2002; Ramachandra Reddy et al., 2004). Also, previous studies indicate that the NAR was relatively lower in drought-stress conditions (Vyas et al., 2001). Increase LAD gave additional advantage to the plant for their development of leaves with large NAR resulting in bolder diameter in corm and large spike with good number of the flower. The production of the dry matter or biomasses of any plant is determined by the higher value of LAD and NAR (Escalante Estrada et al., 1993). Decrease in LAD and NAR was found to be strongly correlated with a decrease in biomass (Chnnappagoudar et al., 2013). Furthermore, studies(Siemens and Zwiazek, 2003) shows that decrease in NAR strongly indicate stomatal closure factor for reduction in the presence of water stress conditions, consequently leads to decline in photosynthesis. It was also observed that the gladiolus cultivar Aarti flowered 4-5 days earlier and sustained flower initiation for a longer period (5-6 days) in comparison to other cultivars indicating that the plant has got more time for sink development and utilization for photoassimilates.

Significant differences were recorded among the cultivars with respect to marketable spikes which were found to be positively and strongly correlated with the LAD and NAR values. Cultivars under present study were varying significantly with respect to the spike length. In a similar type of study, Kamble (2001) reported that maximum spike length, spike weight, diameter of florets, and a number of florets per spike were noticed in cultivar Summer Sunshine and Vedanapali showed maximum spike girth and spike yield per hectare. Accordingly, he found a significant variability in terms of these characters in similar condition. Pragya et al. (2010) also asserted the significant variability among the cultivars of gladiolus in terms of spike length with cultivar Pusa Jyotsna having the longest spike length and cultivar Pusa Jyotsana, and Pusa Swarnima recorded maximum number of florets/spike.

\section{CONCLUSION}

The study indicate that water deficit stress do have a strong impact on plant biomass production influencing production and productivity. Though all the cultivars deviate from its normal characteristics during stress condition but its intensity vary. Those cultivars can be regarded as tolerant that compromise less with their production and productivity. Under similar water stress condition cultivars, Aarti and Suchitra perform best compared to other five cultivars in terms of marketable spikes. The information contained within the genome of each species dictates the plant response to the adverse 
environmental condition. Identification of such traits can be useful toward the development of tolerant varieties.

\section{REFERENCES}

Blumwald E, Anil G, Allen G. New Directions for a Diverse Planet: Proceeding of $4^{\text {th }}$ International Crop Science Congress, $26^{\text {th }}$ September- $1^{\text {st }}$ October 2004, Brisbane, Australia; 2004.

Chartzoulakis K, Patakas A, Kofidis G, Bosabalidis A, Nastau A. Water stress affects leaf anatomy, gas exchange, water relations and growth of two avocado cultivars. Sci Hortic 2002;95:39-50.

Chnnappagoudar BB, Mane SS, Naganagoudar YB, Rathod S. Influence of herbicides on morpho-physiological growth parameters in brinjal (Solanum melongena 1.). Bioscan 2013;8:1049-52.

Colom MR, Vazzana C. Drought stress effects on three cultivars of Eragrostis curvula: Photosynthesis and water relations. Plant Growth Regul 2001;34:195-202.

Dastane NG. A Practical Manual for Water Use Research. Poona, India: Navbharath Prakasan; 1967. p. 5.

Escalante Estrada J, Alberto YJ, Shibata K. El rendimiento y crecimiento del frijol. Manual para toma de datos. Colegio de Postgraduados (Performance and Bean Growth, Manual Data Collection. Graduate College). De Texcoco Méx: Montecillo Mpio; 1993. p. 84.

Gratani L, Catoni R, Varone L. Morphological anatomical and physiological leaf traits on Q.ilex, P. latifolia, P. lentiscus, and $M$. communis and their response to Mediterranean climate stress factors. Bot Stud 2013;54:35.

Jaleel CA, Manivannan P, Kishorekumar A, Sankar B, Gopi R, Somasundaram R, et al. Alterations in osmoregulation, antioxidant enzymes and indole alkaloid levels in Catharanthus roseus exposed to water deficit. Colloids Surf B Biointerfaces 2007;59:150-7.

Jaleel CA, Manivannan P, Lakshmanan GM, Gomathinayagam M, Panneerselvam R. Alterations in morphological parameters and photosynthetic pigment responses of Catharanthus roseus under soil water deficits. Colloids Surf B Biointerfaces 2008;61:298-303.
Jaleel CA, Manivannan P, Sankar B, Kishorekumar A, Gopi R, Somasundaram $\mathrm{R}$, et al. Water deficit stress mitigation by calcium chloride in Catharanthus roseus: Effects on oxidative stress, proline metabolism and indole alkaloid accumulation. Colloids Surf B Biointerfaces 2007;60:110-6.

Kamble BS. Evaluation of Gladiolus (Gladiolus hybridus Hort.) Varieties, M.Sc. (Hort.) Thesis, University of Agricultural Sciences, Dharwad; 2001.

Pompelli MF, Martins SC, Celin EF, Ventrella MC, Damatta FM. What is the influence of ordinary epidermal cells and stomata on the leaf plasticity of coffee plants grown under full-sun and shady conditions? Braz J Biol 2010;70:1083-8.

Pragya P, Bhat KV, Misra RL, Ranjan JK. Analysis of diversity and relationships among Gladiolus cultivars using morphological and RAPD markers. Indian J Agric Sci 2010;80: 135-138.

Ramachandra Reddy A, Chaitanya KV, Vivekanandan M. Drought-induced responses of photosynthesis and antioxidant metabolism in higher plants. J Plant Physiol 2004;161:1189-202.

Shao HB, Chu LY, Jaleel CA, Zhao CX. Water-deficit stressinduced anatomical changes in higher plants. C R Biol 2008;331:215-25.

ShivayYS, Singh RP, Pandey CS. Physiological analysis of growth in maize (Zea mays L.) as influenced by cropping systems and nitrogen levels. Indian J Plant Physiol 2002;7:126-30.

Siemens JA, Zwiazek JJ. Effect of water deficit stress and recovery on the root water relations of trembling aspen (Populus tremuloides) seedlings. Plant Sci 2003;165:113-20.

Thakur PS, Kaur H. Variation in photosynthesis, transpiration, water use efficiency, light transmission and leaf area index in multipurpose agroforestry tree species. Indian J Plant Physiol 2001;6:249-53.

Vyas SP, Garg BK, Kathju S, Lahiri AN. Influence of potassium on water relations, photosynthesis, nitrogen metabolism and yield of cluster bean under soil moisture stress. Indian J Plant Physiol 2001;6:30-7.

Zhao H, Zhang ZB, Shao HB, Xu P, Foulkes MJ. Genetic correlation and path analysis of transpiration efficiency of wheat flag leaves. Environ Exp Bot 2008;64:128-34. 